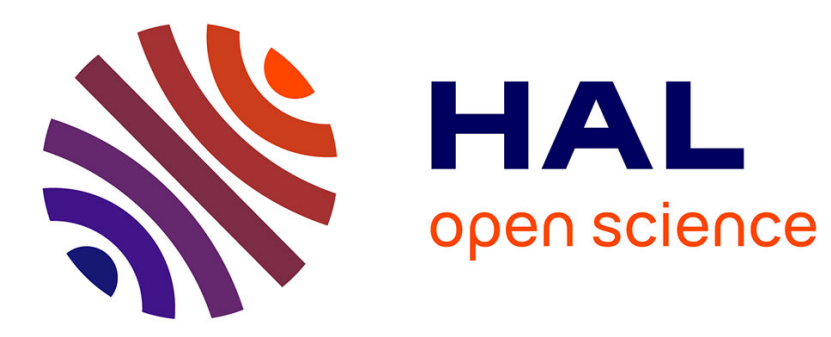

\title{
Rodent models with expression of PMP22: Relevance to dysmyelinating CMT and HNPP
}

Maxime Jouaud, Stéphane Mathis, Laurence Richard, Anne-Sophie Lia, Laurent Magy, Jean-Michel Vallat

\section{- To cite this version:}

Maxime Jouaud, Stéphane Mathis, Laurence Richard, Anne-Sophie Lia, Laurent Magy, et al.. Rodent models with expression of PMP22: Relevance to dysmyelinating CMT and HNPP. Journal of the Neurological Sciences, 2019, 398, pp.79-90. 10.1016/j.jns.2019.01.030 . hal-03333581

\section{HAL Id: hal-03333581 https://hal.science/hal-03333581}

Submitted on 21 Oct 2021

HAL is a multi-disciplinary open access archive for the deposit and dissemination of scientific research documents, whether they are published or not. The documents may come from teaching and research institutions in France or abroad, or from public or private research centers.
L'archive ouverte pluridisciplinaire HAL, est destinée au dépôt et à la diffusion de documents scientifiques de niveau recherche, publiés ou non, émanant des établissements d'enseignement et de recherche français ou étrangers, des laboratoires publics ou privés.

\section{(ㅇ)(1) $\$$}

Distributed under a Creative Commons Attribution - NonCommercial| 4.0 International 


\section{Rodent models with expression of PMP22: relevance to dysmyelinating CMT and HNPP}

Maxime Jouaud $^{\mathrm{a}}$, Stéphane Mathis ${ }^{\mathrm{b}, \mathrm{c}}$, Laurence Richard ${ }^{\mathrm{d}, \mathrm{e}}$, Anne-Sophie Lia ${ }^{\mathrm{a}, \mathrm{f}}$, Laurent Magy $^{\mathrm{d}, \text { e }}$, Jean-Michel Vallat ${ }^{\mathrm{d}, \mathrm{e}^{*}}$

a Equipe d'accueil 6309, Maintenance myélinique et Neuropathies périphériques, University of Limoges, 2 rue du Docteur Raymond Marcland, 87000 Limoges, France.

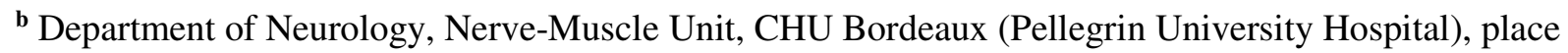
Amélie Raba-Léon, 33000 Bordeaux, France.

C National Reference Center 'maladies neuromusculaires du Grand Sud-ouest', CHU Bordeaux (Pellegrin University Hospital), place Amélie Raba-Léon, 33000 Bordeaux, France.

d Department of Neurology, CHU Limoges, Dupuytren University Hospital, 2 avenue Martin Luther King, 87042 Limoges France.

e National Reference Center for 'Rare Peripheral Neuropathies', CHU Limoges, Dupuytren University Hospital, 2 avenue Martin Luther King, 87042 Limoges France.

${ }^{\mathbf{f}}$ Department of Biochemistry and Molecular Genetics, CHU Limoges, Dupuytren University Hospital, 2 avenue Martin Luther King, 87042 Limoges France.

*Corresponding author at: Department of Neurology, National Reference Center for Rare Peripheral Neuropathies, University Hospital Limoges, 2 avenue Martin Luther King, 87042 Limoges France. Email: address: jean-michel.vallat@unilim.fr (J.M. Vallat) 
Rodent models with expression of PMP22: relevance to dysmyelinating CMT and HNPP 


\begin{abstract}
Background: Charcot-Marie-Tooth diseases (CMT) are due to abnormalities of many genes, the most frequent being linked to PMP22 (Peripheral Myelin Protein 22). In the past, only spontaneous genetic anomalies occurring in mouse mutants such as Trembler (Tr) mice were available; more recently, several rodent models have been generated for exploration of the pathophysiological mechanisms underlying these neuropathies.
\end{abstract}

Methods: Based on the personal experience of our team, we describe here the pathological hallmarks of most of these animal models and compare them to the pathological features observed in some CMT patient nerves (CMT types 1A and E; hereditary neuropathy with liability to pressure palsies, HNPP).

$\underline{\text { Results: }}$ we describe clinical data and detailed pathological analysis mainly by electron microscopy of the sciatic nerves of these animal models conducted in our laboratory; lesions of PMP22 deficient animals (KO and mutated PMP22) and PMP22 overexpressed models are described and compared to ultrastructural anomalies of nerve biopsies from CMT patients due to $P M P 22$ gene anomalies. It is of note that while there are some similarities, there are also significant differences between the lesions in animal models and human cases. Such observations highlight the complex roles played by PMP22 in nerve development.

Conclusion: It should be borne in mind that we require additional correlations between animal models of hereditary neuropathies and CMT patients to rationalize the development of efficient drugs.

Keywords: CMT; animal; model; treatment; PMP22; Trembler. 


\begin{abstract}
Abbreviations
$\underline{\mathrm{AA}}$ : ascorbic acid; $\underline{\mathrm{AD}}$ : autosomal dominant; $\underline{\mathrm{CMT}}$ : Charcot-Marie-Tooth disease; $\underline{\mathrm{CMTde}}$ : dysmyelinating form of CMT; Congenital Hypomyelinating Neuropathy: CHN; $\underline{\mathrm{CNS}}$ : central nervous system; dup: duplication; DNA: deoxyribonucleic acid; DSS: Dejerine-Sottas syndrome; EM: electron microscopy; HNPP: hereditary neuropathy with liability to pressure palsies; $\underline{\mathrm{HSP} 70}$ : heat shock protein 70; $\underline{\mathrm{KO}}$ : knock out; $\underline{\mathrm{MPZ}}$ : myelin protein zero (P0); mRNA: messenger ribonucleic acid; $\underline{\text { NC: }}$ nerve conduction; PMP22: peripheral myelin protein 22; PNS: peripheral nervous system; $\underline{\mathrm{SC}}$ : Schwann cell; $\underline{\mathrm{TgN}}$ : transgenic; $\underline{\mathrm{TM}}$ :

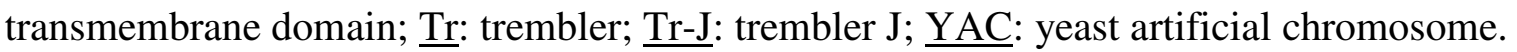




\section{Introduction}

Careful study of naturally occurring and genetically engineered neurological animal mutants can provide information on the causative role of PMP22 (Peripheral Myelin Protein 22) in human peripheral neuropathies induced by $P M P 22$ gene abnormalities [1], and provide insights into the associated disease mechanisms. Before 1995, only spontaneously occurring mouse mutants such as Trembler (Tr) mice were available (Fig. 1). Since then, several Charcot-Marie-Tooth (CMT) rodent models have been generated (Table 1). Analysis of the clinical, biochemical, electrophysiological and pathological data of these animals can help comprehend myelination in the peripheral nervous system and the function of PMP22 in particular. The microscopical nerve anomalies of these animals are characteristic of a dysmyelinating process as they are induced by defects in myelin synthesis; furthermore, no structural destruction is observed.

\section{Method}

Based on other published studies $[1,2]$, we present an updated review of the literature on most of the PMP22-related neuropathies, along with descriptions of the main pathological features of these models. We present here a review and a correlative study rather than a detailed scientific presentation. The review of the literature was conducted by searching in Pubmed, Google Scholar, and Sciencedirect with the following terms: [PMP22 AND Charcot-Marie-Tooth AND animal] OR [PMP22 AND CMT AND animal] OR [PMP22 AND Dejerine-Sottas disease AND animal] OR [PMP22 AND congenital hypomyelinating neuropathy AND animal] OR [PMP22 AND HNPP AND animal] OR [PMP22 AND hereditary neuropathy with liability to 
pressure palsies AND animal]. From the publications found, only those dealing with PMP22-related neuropathies in rodent models were selected.

In our laboratory we have studied the nerves of most of these mutants: we discuss here our personal data (all the micrographs which are presented in this review have been made by the same observer, on at least four blocks of one sensorimotor sciatic nerve of each model). We also discuss the usefulness of these morphological data in the understanding of human nerve lesions examined on pure sensory nerve biopsies (superficial peroneal or sural nerves) and of treatments of hereditary sensorimotor neuropathies such as CMT and HNPP. Nevertheless, it may be argued that pathological studies alone cannot differentiate cellular processes such as differentiation, proliferation or arrest of myelination.

\section{PMP22 deficient mice}

\subsection{PMP22 downregulation models}

These strains are generated by using homologous recombination to inactivate $P M P 22$.

\subsubsection{PMP22 -/- mice}

They develop normally until the second week of life when walking difficulties appear as a consequence of progressive paralysis of the hind limbs. Occasionally mild tremor and stress-induced convulsions are observed. Light and electron microscopy (EM) examinations of the femoral nerve reveal myelin and axon abnormalities; otherwise and surprisingly, many nerve fibers of 24-day-old PMP22-/- mice are characterized by prominent myelin thickenings [3-5]. These structures, which are predominantly localized at paranodes, but may also concern juxta-paranodal and 
internodal regions, consist of redundant myelin loops (tomacula); the corresponding diameter of axons often appear abnormally small (Fig. 2). Large caliber axons devoid of myelin sheaths are also observed, and their ensheathing Schwann cells (SC) are occasionally associated with degenerating myelin. In 10-week-old animals, there are few tomacula, while signs of axonal degeneration are observed. Around thinly myelinated axons, there are numerous concentric proliferations (resembling 'onionbulbs') of basal lamina, and of some SC, suggesting that the observed myelin tomacula may be transient phenomena that degenerate during maturation. PMP22deficient SC form shorter internodes so that nerve conduction velocities are reduced [4].

Absence of PMP22 also results in abnormal myelin formation. At day 4, the large caliber axons of the pectineus nerve are separated from the bundles of nonmyelinated axons and are associated with prospective myelinating SC in a 1/1 ratio. There is a marked delay in myelination that appears to be more significant in motor nerve (roots) than in sensory nerves [4]. In a significant number of SC which contain one small axon (but larger than the usual unmyelinated axons), no mesaxons are detected by careful EM examination. The mesaxon (also termed 'surface-connecting membrane') corresponds to a double membrane formed by the apposition of the external surfaces of a single SC, marking the point of edge-to-edge contact by the SC surrounding the axon [6]. The normal cytoplasmic processes that should make up the mesaxon are either only touching each other or are still quite well separated (Fig. 2). Otherwise, most of the myelin sheaths are normally compacted and one can see all stages of mesaxon formation in these schwannian cytoplasms. Sancho et al. showed that the frequency of dysmyelination was more proximal than distal [4]. 
We have not personally observed the following model; so, we mention here some literature data. The two first coding exons of PMP22 have been replaced by a Lac $\mathrm{Z}$ reporter resulting in a null allele gene. As for the previous model, these homozygous PMP22-deficient mice manifest visible signs of motor deficits, including clasped hind limbs, tremor, and hindered gait noticeable by two weeks of age. At P10, -/- mice show tomacula, a delay in the myelination of large-caliber fibers, and excess concentric proliferation like 'onion-bulbs' of loose basal lamina. In this model, Amici et al. have shown that PMP22 is in a complex with $\alpha 6-\beta 4$-integrin and laminin and that $\beta$-4-integrin levels are reduced in sciatic nerves of PMP22-/- mice; these authors conclude that PMP22 is a binding partner in the integrin/laminin complex and is involved in mediating the interaction of SC with the extracellular environment [7].

\subsubsection{PMP22 -/+ mice}

Pathologically, there are fewer tomacula, and the density of myelinated fibers is close to normal. However, according to our observations by EM, there are a few large and small diameter axons with too thin myelin sheaths and some with a complete absence of myelin can be detected; a few myelin sheaths are also partially uncompacted (Fig. 3 and 4). Nevertheless, it may be argued that pathological studies alone cannot differentiate cellular processes such as differentiation, proliferation or arrest of myelination.

\subsubsection{Human correlations}

\subsubsection{Corresponding to PMP22 -/- mice:}


There are scant reports of patients with mutations on the two PMP22 alleles. We have observed a patient with two compound mutations in the PMP22 gene: the point mutation causing a premature STOP codon in $P M P 22$ exon 3 was inherited from the mother in the first allele and the 'typical deletion' on the PMP22 gene in the region 17q11.2 was inherited from the father on the other allele [8]. By PMP22 mRNA quantitation, we showed a complete lack of $P M P 22 \mathrm{mRNA}$ resulting in complete absence of PMP22 protein. Pathological study of a sensory nerve (sural) (Fig. 5) revealed an absence of myelin sheaths and of inner normal mesaxons which are the connection between the myelin sheaths and the inner part of the cell membrane of SC. Each axon which should be myelinated is surrounded by an intense concentric proliferation of basal lamina and a few elongated fragments of SC cytoplasms.

Similar lesions have also been described by Al-Thihli et al.: this patient had a compound deletion including the typical $1.5 \mathrm{Mb} P M P 22$ deletion inherited from his mother and a smaller deletion of exons 2 and 3 from his father [9]. Another patient with a homozygous complete deletion of the entire $P M P 22$ gene has been reported by Saporta et al. who reported in the myelinated dermal nerves of the skin "a profound reduction in myelinated fiber density" but not a complete absence [10]. As suggested by Saporta et al., the differences between this patient and our patient's phenotype may simply represent a phenotypic variability [10]; alternatively, truncated $P M P 22$ from one of the alleles may cause 'toxic' gain of function that leads to a more severe phenotype. Two other patients with a T118M mutation on one allele and a deletion of the PMP22 gene have been reported. In these latter cases, it has been shown (in tissue cultures) that the mutated PMP22 protein is sequestrated in the endoplasmic reticulum [11]. A 31/2 year-old girl with a $P M P 22$ compound deletion has also been reported: a severe reduction or complete lack of PMP22 protein has been demonstrated in most of 
these cases $[9,10,12]$. In the sensory nerves of these patients, there is no myelin, so no tomacula and no other microscopical lesions (such as macrophages or apoptosis) were observed. Since this nerve biopsy came from the distal part of a sensory nerve, it might be argued that some lesions such as tomacula could exist at other sites of the nerves. Nevertheless, as these patients are all clinically severely and diffusely impaired and nerve conduction studies indicate a severe and diffuse sensory-motor polyneuropathy, it can be assumed that the amyelinating process is diffuse. It should be borne in mind that, in humans, only sensory nerves can be biopsied and examined microscopically; but, in mice sciatic nerves are sensorimotor and can thus be examined together.

\subsubsection{Corresponding to PMP22 -/+ mice:}

Adlkofer et al. have shown that heterozygous PMP22 KO mice, which carry only one functional PMP22 allele and thus genetically mimic HNPP, display pathological and electrophysiological features similar to those observed in HNPP [3]. Fledrich et al. mentioned that these mice lack an obvious clinical phenotype comparable to that of mildly affected patients [1]; nevertheless, it has been shown by Bai et al. that the $P M P 22+/-$ mice nerves are susceptible to mechanical pressure [13].

In most HNPP human cases, a 1.5 Mb DNA heterozygous deletion is found [14]. This deleted region includes the PMP22 gene, leading to haplo-insufficiency at this locus and under-expression of the PMP22 protein in compact myelin $[15,16]$. So, deletion of $P M P 22$ gene in HNPP patients and reduction in $P M P 22$ gene expression in the mouse models induce an increase in myelin thickness in paranodes only where tomacula are formed (Fig. 6A and 6B) [17]. In these mice and in HNPP, tomacula 
commonly lead to severe constriction of axons [7, 13]. Considering these observations, PMP22 may have a role in the regulation of myelin thickness, but a pathway involving PMP22 in this process yet to be identified. The fundamental perturbation is $P M P 22$ gene dosage $[15,18]$.

\subsection{PMP22 mutation models}

Trembler models (autosomal dominant transmission) are spontaneous mice mutants presenting very severe clinical signs, moving with difficulty (spastic paresis) and developing generalized tremor and transient seizures (tonico-clonic convulsions) at an early age (after 1014 days of age); most animals remain viable into adulthood. In the mid-1970s, hypertrophic peripheral neuropathy was observed in such models [19].

The autosomal dominant Trembler (Tr) mutation maps to mouse chromosome 11 and manifests as a SC defect characterized by severe hypomyelination and continuing SC proliferation throughout life; this spontaneous, dominantly inherited PMP22 mutation results in a point mutation (identified by Suter $e t$ al. in 1992) that substitutes an aspartic acid residue for a glycine at amino acid position 150 , in the $4^{\text {th }}$ transmembrane region of the PMP22 protein [20].

Trembler-J (Tr-J) were named after the Jackson laboratory that produced them from the C57BL/6J strain of $\operatorname{Tr}$ mice [21]. Tr-J carries a point mutation (new mutant allele at thr $\operatorname{Tr}$ locus) which replaces a leucine with a proline residue at amino acid position 16 (L16P) in the first transmembrane domain of PMP22 [22]. As for Tr mice, Tr-J mice present a phenotype of progressive limb weakness and tremor. 
Both Tr and Tr-J share pathological features with PMP22-related CMT [22]: in particular, Trembler model was considered as the first animal model of CMT related to point mutations of the PMP22 gene (CMT1E) [23].

\subsubsection{The trembler mouse model ( $\mathrm{Tr}$ )}

\subsubsection{Homozygous}

Nerve pathological alterations are quite significant and indicate a hypomyelinating process. Although a few small-caliber myelinated axons display typical myelin sheaths of a nearly normal thickness, most axons of caliber that would normally be fully myelinated have no myelin sheath or are surrounded by an abnormally thin one. There are proliferations of loose basal lamina around the SC (reminiscent of the 'onion-bulb' patterns) (Fig. 7A and 7B) [23, 24].

\subsubsection{Heterozygous}

Heterozygous mice show features of severe hypomyelination, but less pronounced than in Tr-/-. Although all large caliber axons are associated with SC, only $10 \%$ are thinly myelinated in Tr-/+ animals (Fig. 8A) (count was done on at least 100 large caliber axons in 3 animals, all 3.5-month-old). SC cytoplasm extensions start surrounding one axon, but frequently the two extensions appear to stop at variable distances before contact, so that they incompletely wrap the axons (Fig. 8B).

Myelinated fibers display absence of 'terminal bands' (also known as 'transverse bands' or 'septate-like junctions') in paranodal and nodal regions so that the junctional gaps between myelin loops and axons are widened [25]; these anomalies 
could contribute significantly to conduction defects and increase risk of myelin detachment. Robertson et al. described also terminal loops of the myelin sheaths turning outwards into the extracellular space instead of inwards to terminate on the axon [23]. These lesions, together with defective differentiation of axolemmal ion channel domains and diminution in nodal voltage-gated sodium channel density, explain conduction defects in $\operatorname{Tr}$ nerves [25].

\subsubsection{The trembler-J mouse model (Tr-J)}

\subsubsection{Homozygous}

Comparatively to heterozygous Tr-J mice, homozygous Tr-J mice are easily recognizable phenotypically by 8 days of age, after which they become progressively unable to walk, as they suffer from a severe peripheral neuropathy with a strong tremor, paralysis of the rear trunk and a lack of muscle tone; all these symptoms and signs are definitively much more severe in homozygous Tr-J: they die prior to weaning, which suggests that peripheral myelin is not essential for survival. In Tr-J-/-, PNS is nearly devoid of myelin with myelinogenesis blocked at the promyelin stage (less than $2 \%$ of the singly ensheathed axons being myelinated).

The mechanisms of dysmyelination in the various Tr mice might be explained by a failure of the mutant $P M P 22$ to be incorporated into the plasma membrane; this protein is supposed to be retained in the endoplasmic reticulum (ER) of myelinating SC [26]. Aggregates containing ubiquitin and PMP22 have been immunostained in SC cultures from the Tr and Tr-J mouse models; the turnover rate of the newly synthesized PMP22 is reduced, suggesting proteasome impairment [27, 28]. Nevertheless, to our knowledge, such aggregates have not been observed (by EM) in 
the cytoplasm of the SCs of nerves from CMT1A patients or from animal models. Also, there is no tomacula formation, which would correspond to a dominant negative effect of the mutant PMP22, so other mechanisms are probably involved such as ER stress.

\subsubsection{Heterozygous}

Mice heterozygous for the Tr-J spontaneous mutation are similar to heterozygotes carrying the original trembler mutation $(P m p 22 T r)$. They display a normal life span and develop only a mild late onset dysmyelinating neuropathy (Fig. 9A) [29]; clinical symptoms/signs and neuropathology of heterozygotes are less severe than for homozygotes. Tremor cannot be reliably recognized before 20-25 days. There are no obvious seizures and only a mild gait abnormality. In the PNS, the myelin deficiency is less severe than that of heterozygous Tr mice: only $30 \%$ of large caliber fibers are not myelinated, and 60\% are thinly myelinated (count was done on 100 fibers in three 3.5 months heterozygous Tr-J mice). There are many fibers with irregular contours of SC cytoplasms and some lesions of uncompacted myelin lamellae (Fig. 9B). The proportion of myelinated fibers increases with age [23].

\subsubsection{Other trembler models}

A few other models have been described, but we have not studied them ourselves.

\subsubsection{Trembler-Ncnp}


These animals are distinguishable from normal littermates by 15-20 days of age. Their gait abnormality increases slightly with age; however, their life span is normal [30]. This mutant is induced by a spontaneous autosomal dominant PMP22 exon 4 deletion coding for the second and a part of the third transmembrane domain of the PMP22 protein.

No myelin is found in the sciatic nerves in the homozygotes at postnatal day 9, at one month and at five months of age. Development appears to stay at the promyelinating stage, with axons ensheathed but not myelinated by the SC cytoplasms. In the heterozygotes, dysmyelination is variable along individual fibers; myelin compaction is normal. No pathological alteration has been found in the CNS.

\subsubsection{Trembler-m1H, tr-m2H and tr-m3H}

These mice exhibit a marked resting tremor and are smaller than littermates at weaning, remaining so in adulthood. They are inactive, exhibiting low locomotor activity. Tr$\mathrm{m} 1 \mathrm{H}$ are more severely affected [31, 32].

Trembler M1H (Tr-m1H) have a PMP22 point mutation; a HisGln mutation has been identified at this site in a case of Dejerine-Sottas syndrome (DSS) [33]. Trembler m2H (Tr$\mathrm{m} 2 \mathrm{H}$ ) has a terminal $P M P 22$ point mutation that truncates the protein by seven amino acids; Trembler $\mathrm{m} 3 \mathrm{H}(\mathrm{Tr}-\mathrm{m} 3 \mathrm{H})$ is linked to another $P M P 22$ point mutation $[31,32]$.

Pathologically, there is no anomaly of the CNS; on peripheral nerve EM examination, there is a significant hypomyelination: the scant myelin sheaths are thin with surrounding axons of small diameter. There is axonal loss and increase in the amount of endoneurial connective tissue [32]. 


\subsubsection{Human correlations}

In humans, PMP22 point mutations account for only $1.4 \%$ of all CMT cases [34] and mostly underlie the severe forms of genetic dysmyelinating neuropathies which sometimes may be included in syndromes such as 'Congenital Hypomyelinating Neuropathy' (CHN) and the so-called 'Dejerine-Sottas syndrome' (DSS). Some of us have recently suggested that these entities ('DSS' and 'CHN') should be abandoned for greater simplicity [35]. Otherwise, neuropathies caused by PMP22 point mutations belong to the CMT1E subtype (dominant CMT dysmyelinating PMP22 mutation; OMIM 118300), which corresponds to these various types of Tr. For instance, we observed a 5-year-old boy who presented delayed motor development, generalized hypotonia, areflexia, and bilateral steppage; nerve conduction (NC) studies showed evidence of a severe peripheral neuropathy (motor NC velocity was $14 \mathrm{~m} / \mathrm{s}$ on the right median nerve); genotyping revealed a c.215C > T (Ser72Leu) heterozygous mutation; sural nerve biopsy showed a quite severe axonal loss, several remaining axons were devoid of myelin and others were surrounded by overly thin myelin sheaths (Fig. 10A and 10B). Cases linked to the same mutation have been reported by Simonati et al., Planté-Bordeneuve et al. and Marques et al. [36-38] who described similar microscopical lesions to those we observed in the nerve biopsy of our patient. As already mentioned, this mutation has also been reported in the Tr-m3h mouse $[31,32]$.

In 1992, Valentijn et al. first reported a CMT1A patient with the same mutation on the PMP22 gene than Tr-J mice [33]. Madrid et al. reported the case of a young patient with a long early-onset history of CMT1E due to a p.Leu18Arg missense mutation in the first transmembrane domain of PMP22, as for the Tr-J mouse; in both nerves of the patient and the Tr-J, there were typical signs of a significant dysmyelinating process and some uncompacted myelin sheaths [39]. A few other ultrastructural studies of nerves of patients with various 
dominant PMP22 mutations have been described [40-44]: there were similar lesions to our case such as basal lamina concentric proliferations like 'onion-bulbs', but complete absence of myelin has not been reported. Nerve biopsy reported by Fabrizi et al. showed also prominent uncompacted myelin sheaths and frequent tomacula [45].

Trembler mice are characterized by PMP22 misfolding, not by PMP22 overexpression, with different subcellular consequences [46]. Finally, Trembler mice are not good models for the human gene dosage disorder CMT1A: in such cases, PMP22 overexpression models (modelled by transgenic extracopies of the wildtype $P M P 22$ gene) are more valid [2].

\subsection{PMP22 overexpression models}

\subsubsection{Rats}

These rats represent a model of CMT1A. PMP22 duplication causes this CMT subtype which accounts for more than half of all CMT cases and about $70 \%$ of CMT1 cases. PMP22 with copy numbers ranging from 3 to 16 have been randomly inserted into the rodent genome [47].

Heterozygous rats display an unsteadiness of gait. They carry a genomic construct encoding three copies of the mouse wild type PMP22 protein on one allele, in addition to the two normal copies of PMP22, resulting in about a 1.6-fold mRNA overexpression in peripheral nerves when quantified by quantitative polymerase chain reaction. General hypomyelination of the PNS is obvious. Many axons have thin or absent myelin sheaths, but the degree of hypomyelination differs between individuals (Fig. 11A and 11B). In 6-month-old rats, we noted moderate axonal loss and increase in 
connective tissue. Hypomyelination is more marked in larger diameter fibers. At ultrastructural level, myelin lamellae are normally compacted. Ventral roots are markedly more affected than the dorsal ones [47]. Clinical phenotype, dysmyelination and axonal loss are more severe in old rats [17].

Homozygous rats display a severe and uniform phenotype which can be diagnosed from the third postnatal week: overall development appears to be retarded, so that animals never develop normal motor function with hind limb paralysis and uncoordinated movements; many animals die prematurely. They carry three copies of the mouse wild type $P M P 22$ on the two alleles. This strong phenotype is linked to a complete lack of myelin on semi-thin sections; endoneurial collagen and SC nuclear numbers are increased [47]. We have studied four nerves of 6-month-old rats by EM at several sites: sensory roots of several posterior root ganglions, sciatic, tibial and peroneal nerves; we found that a few axons had a very thin myelin sheath (Fig. 12A and 12B). SCs are present and have segregated axons at the normal 1:1 ratio. In many SC, cytoplasm extensions start surrounding one axon, but frequently the two extensions appear to stop at variable distances before contact, so that they incompletely wrap the axons; sometimes, these two narrow extensions of the SC cytoplasm may be in contact. These anomalies remain unchanged even at several months of age. Typical 'onion bulbs', showing concentric layers of a few SC processes and redundant basal laminae around SC, are clearly seen by EM in about $40 \%$ of the dysmyelinated and amyelinated fibers; endoneurial collagen is markedly increased.

Using immunohistochemical quantitative analysis (immunogold) of PMP22 on nerve biopsies of CMT1A and HNPP, we showed elevated and reduced expression (respectively) of PMP22 compared with controls [15]. Using the same technique in these animals, a manual quantitative analysis of gold particles density was performed on 
EM micrographs at the same magnification. For technical reasons, we were only able to study PMP22 expression in one normal, one transgenic heterozygous and one homozygous CMT1A rat on five different nerve sections. PMP22 is expressed in myelin with a ratio of 1 gold particle/ $\mu \mathrm{m}^{2}$. In the normal rat, 13 different myelin sheaths were studied on each of the five sections. PMP22 is relatively well expressed in the SC cytoplasms. In the heterozygous rat (15 different myelin sheaths on each of the 5 sections), PMP22 protein concentration is abnormally increased. There are approximately 1.7 gold particles/ $\mu \mathrm{m}^{2}$ of myelin, and PMP22 is also expressed in the SC cytoplasm. In homozygous rats, myelinated fibers are extremely rare (with a reduced ' $\mathrm{g}$ ratio'), but in the myelin of these rats (only 3 different myelin sheaths could be detected on each of the 5 sections), PMP22 is strongly overexpressed with a ratio of approximately 10.6 gold particles $/ \mu \mathrm{m}^{2}$ of myelin. PMP22 is also strongly expressed in myelinating SC cytoplasms and in the cytoplasm of SCs which failed to myelinate axons (Fig. 13A, 13B, 13C and 13D).

\subsubsection{Mice}

We have not studied these models personally. These mice show a dominant phenotype of weakness and progressive paralysis of the hind legs. This CMT1A murine model is very close to a transgenic mouse model called ' $\mathrm{C} 22$ ' with 7 copies of $P M P 22$ $[23,48,49]$. There is a widespread dysmyelination of large axons which are surrounded by an overly thin myelin sheath, whereas small myelinated fibers appear well preserved. SC processes forming 'onion bulbs' are present around some dysmyelinated axons.

Other generations of transgenic mice (carrying one, two, four, or eight copies of the PMP22 gene on a YAC, or 'yeast artificial chromosome') have been described [50]. 
In mice with one or two copies of the transgene, there are no detectable phenotypic abnormalities, with only minor pathological lesions. Mice with four PMP22 copies, called C61 do not move as smoothly as the wild type or as mice with one or two copies of PMP22. These mice have been crossed in order to obtain homozygous mice with 8 copies of PMP22. C61 mice could not be distinguished morphologically from controls either at P4 or P12, although, by 6 weeks, a small subgroup of the larger myelinated axons are hypomyelinated [50]. Mice with 8 copies present essentially the same clinical deficits as the C22 mouse line [23]. In these animals, the level of human transgene expression is roughly proportional to the copy number of the YAC transgene.

Based on the known promyelinating effect (in vitro) of ascorbic acid in SC and dorsal root ganglia co-cultures, a study of the therapeutic effect of ascorbic acid was conducted in C22 mice: it confirmed a positive effect (in vivo) on peripheral nerves [50, 51]. However, several studies have failed to show benefit of ascorbic acid in CMT1A patients (cf. next paragraph). Overexpression of PMP22 may affect SC in different ways [52]. It causes apoptosis, but this mechanism is supposed to act only in aged SC, while dysmyelination is present very early. Otherwise, it is recognized that PMP22 overexpression induces blockade of the protein degradation system, leading to formation of protein aggregates [28, 53]. The accumulation of misfolded PMP22 activates and upregulates ergastoplasm and/or auto-lysosomal systems, so that the proteasome is not efficient in mutant $\mathrm{SC}$ which dedifferentiate; thus, there is an activation of proteostatic mechanisms. Moreover, cytosolic chaperones are consistently elevated in nerves from transgenic C22 mice, with the most prominent change in HSP70 [54]. Positive effects of chaperone in preventing aggregation and improving the trafficking of PMP22 are well described. Chittoor-Vinod et al. (using fibroblasts from CMT1A patients) showed that increase of HSP70 expression attenuates proteasome 
dysfunction [55]. It should be noted that these mice have seven copies of the PMP22 gene, while CMT1A patients have only three copies. Along with other pathologists, we have not observed any cytoplasmic protein aggregates on several nerve biopsies from CMT1A patients, which have been described by immunohistochemistry in patients with Trembler or Trembler-J mutations [56].

\subsubsection{Human correlations}

The genetic defect of CMT1A, clinically characterized by bilateral peroneal atrophy, skeletal deformities (including pes cavus), decrease or absence of tendon reflexes, and electrophysiologically characterized by homogeneous dysmyelination with diffuse reduced NC velocities, is an intra-chromosomal duplication on chromosome 17p11.2. PMP22 is located within the duplicated region; its increased gene expression induces the disease. Pathologically, there is axonal loss and thin myelin sheaths confirming the dysmyelinating process, often surrounded by proliferations of concentric SC elongated fragments like 'onion bulbs' [57]. In the heterozygous rat model, we observed similar but much less severe lesions at 6 months. A patient homozygous for the duplication has been reported and is clinically more severe than normal with onset before year one, corresponding to $\mathrm{CHN}$ [58].

\section{New therapies on these models}

The PMP22 gene encodes for a small membrane protein $(22 \mathrm{kDa})$, one of the components of compact myelin (the insulating sheath to axons, serving to facilitate rapid conduction of electric impulses) in the PNS, with also MPZ (myelin protein zero) and MBP (myelin basic protein) [59]. PMP22 consists of 160 amino acids containing four transmembrane domains, two cytoplasmic arms, a short intracellular loop and two 
extracellular loops. The PMP22 protein is of diffuse expression in the embryonic stage, including the central nervous system (CNS). On the other hand, in adulthood, while it is clearly expressed in SC (where it represents 2-5\% of compact myelin), it also remains very weakly expressed in the CNS (cortex, brainstem, spinal cord), particularly in the motor nuclei of cranial nerves and peripheral motor neuron nuclei, as well as in certain non-nervous tissues (skeletal muscle, heart) [52]. Alterations of the PMP22 gene are a major cause of several hereditary demyelinating peripheral neuropathies such as Charcot-Marie-Tooth diseases (CMT) type 1A (duplication) and 1E (mutations) or hereditary neuropathy with liability to pressure palsies (HNPP; deletion). However, the exact function of PMP22 is still poorly understood: it is assumed to play a role in proliferation, differentiation, and death of Schwann cells (SC) [60-62], and also may play an essential role in the functioning of neurons expressing it at early stages of embryonic development [10]. Moreover, it has been suggested that PMP22 could provide mechanical support to nerves [13] and nerve fibers [63], as well as contributing significantly to the mechanoprotective action of the SCs basal lamina [64]. Another crucial role of PMP22 is the sealing, tightening and stabilization of myelin through its involvement in the assembly of myelin junctions [65].

It is now well accepted that lowering the toxic overexpression of the PMP22 gene in CMT1A can be an efficient strategy [66]. Progesterone antagonists which decrease PMP22 overexpression and ameliorate the clinical phenotype of CMT rats might be of value, but at the present time, the drug (which is available for humans) affects liver function [17]. Otherwise, the combination of three well known and approved drugs (baclofen, naltrexone and sorbitol) has improved myelination in rat models of CMT1A. It down-regulates the expression of PMP22 in cultured SC. The tests performed in a nerve crush mouse model demonstrate the acute neuroregenerative and promyelinating potential of this drug combination [67]. A phase 2 trial has now been conducted and has recently provided first 
indications of therapeutic activity in mild to moderately affected adult CMT1A patients. A phase III trial is ongoing.

As mentioned above, ascorbic acid (AA, or vitamin $\mathrm{C}$ ) has been shown to be required for correct myelination of peripheral nerves in vitro and in vivo [68]. Furthermore, AA improved muscle function and reduced dysmyelination in a mouse model of CMT1A [51]. A recent Cochrane review has discussed six randomized trials which compared the effect of oral AA (1-4 grams) and placebo treatment in CMT1A [68]. It has been concluded that AA does not improve the course of CMT1A either in adults or children.

Therapeutic application of Neurotrophin-3 in immune incompetent mice with xenograft transplants of sural nerve biopsies from with CMT1A (as well as from Tr-J mice) augmented axonal regeneration. A clinical pilot study was carried out in CMT1A patients. Increase in myelinated fiber density, reduction in the neurological impairment score, as well as improved sensory modalities were observed [69].

Recently, Fledrich et al. have shown that myelinating SCs in the rat model of CMT1A present a reduced transcription of genes required for myelin lipid biosynthesis which induces a reduced myelin lipid content: substitution of phosphatidylcholine and phosphatidylethanolamine in the diet appears to overcome the reduced myelination in affected Schwann cells. This specific regimen is thought to rescue the number of myelinated axons in peripheral nerves and induces a significant improvement of the neuropathic symptoms [70].

Another approach to reduce PMP22 expression may be a direct therapeutic strategy targeting PMP22 RNA with antisense oligonucleotides (ASOs) that are single-stranded synthetic nucleic acids that bind target mRNA via Watson-Crick base pairing, resulting in degradation of target mRNA. Recently, Zhao et al. showed that reduction of PMP22 mRNA in skin biopsies from ASO-treated CMT1a rats (C22) could be a suitable biomarker for 
evaluating target engagement in response to ASO therapy [71]; Lee et al. have also shown that administration of mutant allele-specific siRNA can ameliorate the demyelination phenotype of Tr-J mice [72].

\section{Conclusions and future directions}

The recognition of rodent strains that bear alterations of the $P M P 22$ gene and the development of transgenic models has enabled clinical and pathological studies of the symptoms, signs, and lesions induced by an absence or overexpression of the PMP22 protein in the PNS. Data from these animal models can be compared with observations on patients with hereditary neuropathies of the CMT type: including the most common CMT1A subtype (linked with an increase in PMP22 protein), the much rarer CMT1E subtype (induced by a mutation of PMP22), and HNPP (giving rise to a reduction in PMP22). Study of these models can help comprehend the complex roles played by PMP22 in nerve development. These spontaneous and transgenic rodents reveal that PMP22 might be involved in the initial spiraling of myelin in early nerve development, determination of myelin thickness, and maintenance of myelin. Furthermore, in some models, it is possible to test therapeutic strategies for CMT and devise guidelines for human clinical trials. It should nevertheless be borne in mind that these animal models present some differences with the subtypes of CMT, which may in part explain the lack of success of the initial clinical trials in man (CMT1A). These limitations with the animal models have been discussed recently, stressing that there are differences in physiology with humans and with the expression of the gene pattern [73]. 


\section{Ethics approval}

The experimental research on murine models was conducted at the University of Limoges ('Laboratoire maintenance myélinique et neuropathies périphériques, EA 6309) after approval from our local ethics committee: Comité Régional d'Ethique de l'Expérimentation Animale du Limousin (CREEAL).

\section{Consent for publication}

Written consent was obtained from each patient undergoing nerve biopsy (seen in Figures 4, 5,10, and 14)

\section{Authors' contribution}

MJ, SM and JMV wrote the manuscript. JMV and LR were involved in image acquisition. LR, ASL and LM provided constructive feedback on several drafts of the manuscript. All approved the final draft for submission.

\section{Competing interests}

The authors declare that they have no competing interests.

\section{Funding}

For the remaining authors (MJ, SM, LR, ASL, LM and JMV) none were declared. 


\section{Availability of data and supporting materials section}

Pathological studies were carried out at the University of Limoges ('Laboratoire maintenance myélinique et neuropathies périphériques, EA 6309) using a JEOL 1011 electron microscope. CMT1A rats were supplied by the Nave lab: Zentrum für Molekulare Biologie, University of Heidelberg, D-69120 Heidelberg, Germany.

\section{Acknowledgments}

We are grateful to the members of the Nave lab for supplying CMT1A rats used in this study and to $\mathrm{J} \mathrm{Li}$ for the PMP $22 \mathrm{KO}$ mice. 
Table 1. Main animal models linked to an alteration in the PMP22 gene (n.a.: not available, NCV: Nerve conduction velocities).

Fig. 1. Main steps in the discovery of genetic analysis of hereditary neuropathies and their first animal models (before 1996).

Fig. 2. Electron micrograph: transverse section of a homozygous $P M P 22 \mathrm{KO}$ mouse sciatic nerve ( 2 months old). $\underline{\text { A: }}$ There are many tomaculous lesions which are much more numerous than in the sciatic nerve of a heterozygous mouse. (C: capillary). $\underline{B}$ : Non-myelinated axons (A); cytoplasmic prolongations (arrows) are widely separated (and do not make up a mesaxon).

Fig. 3. Electron micrograph: transverse section of a heterozygous $P M P 22 \mathrm{KO}$ mouse sciatic nerve (2 months old). $\underline{A}$ : Numerous signs of dysmyelination: myelin sheaths overly thin with respect to axon diameter (arrows). B: Some myelinated fibers with non-compacted myelin (star). $\underline{\mathrm{C}}$ : Only a few axons are not myelinated; the mesaxon is very small (arrow). $\underline{\mathrm{D}}$ : A few myelinated fibers with tomaculous lesions (arrow); note the reduction of axon diameter (A: axon).

Fig. 4. Count of large non myelinated and dysmyelinated fibers and tomacula of normal, heterozygous $P M P 22+/-$ and homozygous PMP22-/- rat nerves. At least 100 large fibers were counted in 3 animals ( 3 normal, 3 homozygous and 3 heterozygous) of 1 year-old age. The ratio is indicated on $\mathrm{Z}$ :axis (number of tomacula per nerve surface; number of unmyelinated fibers per nerve surface; number of dysmyelinated per nerve surface). 
Fig. 5. Electron micrograph: transverse section of a 3 and a half year-old patient CMT1A with a deletion on one allele of $P M P 22$ and a non-sense mutation on the other one. $\underline{\mathrm{A}}$ : There is a complete absence of myelination around axons (sural nerve). $\underline{\mathrm{B}}$ : The cytoplasmic prolongations (arrows) are too far apart to form a mesaxon (stars: concentric proliferations of fragments of basement membranes; A: axon).

Fig. 6. $\underline{A}$ : Nerve teasing of an HNPP patient showing tomaculous aspect. $\underline{B}$ : Electron micrograph: transverse section of an HNPP patient nerve (A: axon).

Fig. 7. Electron micrograph: transverse section of a 3-month-old homozygous trembler mouse sciatic nerve. $\underline{\text { A: }}$ Complete absence of myelination around axons. $\underline{B}$ : There is a gap (arrow) between the Schwann cell processes, with excessive endoneurial collagen fibers.

Fig. 8. Electron micrograph: transverse section of a 3 month old heterozygous trembler mouse sciatic nerve. A : All myelin sheaths are overly thin and many axons are not myelinated. B: Non myelinated axon showing, as in Fig. 7, that the cytoplasmic prolongations (arrows) are too far apart to form a mesaxon (stars: concentric proliferations of basement membrane fragments; A: axon). 
Fig. 9. Electron micrograph: transverse section of a 6-month-old heterozygous trembler-J mouse sciatic nerve. $\underline{A}$ : Numerous overly thin myelin sheaths (arrows). $\underline{B}$ : Non-compacted myelin (stars) (A: axon).

Fig. 10. Electron micrograph: transverse section of an 11 year-old age CMT1E patient sural nerve. $\underline{\text { A}}$ : Numerous axons with complete absence of myelination; others have overly thin myelin sheaths. $\underline{B}$ : The cytoplasmic prolongations of Schwann cells join but do not overlap (arrows) (A: axon).

Fig. 11. Electron micrograph: transverse section of a 6 month-old heterozygous CMT1A rat sciatic nerve. $\underline{\text { A: }}$ There are several overly thin myelin sheaths. $\underline{B}$ : Magnification of A (the small axons are normally myelinated, but the large axon has an overly thin myelin sheath).

Fig. 12. Electron micrograph: transverse section of a 6 month-old homozygous CMT1A rat sciatic nerve. $\underline{\mathrm{A}}$ : There is a complete lack of myelin sheaths. $\underline{\mathrm{B}}$ : At high magnification, it has been possible to detect very thin myelin sheaths around a few large diameter axons (A: axon).

Fig. 13. $\underline{\mathrm{A}}$ : PMP22 expression (arrows) in a normal rat (wild type, wt). $\underline{\mathrm{B}}$ : PMP22 expression in a heterozygous 3 month-old CMT1A rat nerve. $\underline{\mathrm{C}}$ : PMP22 expression in a homozygous 3 month-old CMT1A rat nerve (embedding in London Resin White). D: PMP22immunostaining (12 nm gold particles) is observed on myelin sheaths. Gold particles were counted on 15 fibers on five sections from a heterozygote and 3 fibers from a homozygote ( $p$ $=0.0008$, heterozygote vs. normal; $\mathrm{p}<0.0001$, heterozygote vs. homozygote). The 
concentration of PMP22 protein in the myelin was 1.7-fold higher in the heterozygous

CMT1A animals with respect to normal animals, and 10-fold higher in the homozygous CMT1A animal compared to normal animals (mean values: 1,081 particles/ $\mu \mathrm{m}^{2}$; heterozygous: 1,744 particles $/ \mu \mathrm{m}^{2}$; homozygous: 10,57 particles $/ \mu \mathrm{m}^{2}$; bar scale $=1 \mu \mathrm{m}$ ). 


\section{References}

[1] Fledrich R, Stassart RM, Sereda MW. Murine therapeutic models for Charcot-MarieTooth (CMT) disease. Br Med Bull. 2012;102:89-113.

[2] Sereda MW, Nave KA. Animal models of Charcot-Marie-Tooth disease type 1A. Neuromol Med. 2006;8:205-16.

[3] Adlkofer K, Frei R, Neuberg DH, Zielasek J, Toyka KV, Suter U. Heterozygous peripheral myelin protein 22-deficient mice are affected by a progressive demyelinating tomaculous neuropathy. J Neurosci. 1997;17:4662-71.

[4] Sancho S, Magyar JP, Aguzzi A, Suter U. Distal axonopathy in peripheral nerves of PMP22-mutant mice. Brain. 1999;122:1563-77.

[5] Adlkofer K, Martini R, Aguzzi A, Zielasek J, Toyka KV, Suter U. Hypermyelination and demyelinating peripheral neuropathy in Pmp22-deficient mice. Nat Genet. 1995;11:274-80. [6] Peters A. The structure of the peripheral nerves of the lamprey (Lampetra fluviatilis). J Ultrastruct Res. 1960;4:349-59.

[7] Amici SA, Dunn WA, Jr., Murphy AJ, Adams NC, Gale NW, Valenzuela DM, et al. Peripheral myelin protein 22 is in complex with alpha6beta4 integrin, and its absence alters the Schwann cell basal lamina. J Neurosci. 2006;26:1179-89.

[8] Jouaud M, Gonnaud PM, Richard L, Latour P, Ollagnon-Roman E, Sturtz F, et al. Congenital hypomyelinating neuropathy due to the association of a truncating mutation in PMP22 with the classical HNPP deletion. Neuromuscul Disord. 2016;26:316-21.

[9] Al-Thihli K, Rudkin T, Carson N, Poulin C, Melancon S, Der Kaloustian VM. Compound heterozygous deletions of PMP22 causing severe Charcot-Marie-Tooth disease of the Dejerine-Sottas disease phenotype. Am J Med Genet A. 2008;146A:2412-6.

[10] Saporta MA, Katona I, Zhang X, Roper HP, McClelland L, Macdonald F, et al. Neuropathy in a human without the PMP22 gene. Arch Neurol. 2011;68:814-21. 
[11] Naef R, Suter U. Impaired intracellular trafficking is a common disease mechanism of PMP22 point mutations in peripheral neuropathies. Neurobiol Dis. 1999;6:1-14.

[12] Abe KT, Lino AM, Hirata MT, Pavanello RC, Brotto MW, Marchiori PE, et al. A novel stop codon mutation in the PMP22 gene associated with a variable phenotype. Neuromuscul Disord. 2004;14:313-20.

[13] Bai Y, Zhang X, Katona I, Saporta MA, Shy ME, O'Malley HA, et al. Conduction block in PMP22 deficiency. J Neurosci. 2010;30:600-8.

[14] Inoue K, Dewar K, Katsanis N, Reiter LT, Lander ES, Devon KL, et al. The 1.4-Mb CMT1A duplication/HNPP deletion genomic region reveals unique genome architectural features and provides insights into the recent evolution of new genes. Genome Res. 2001;11:1018-33.

[15] Vallat JM, Sindou P, Preux PM, Tabaraud F, Milor AM, Couratier P, et al. Ultrastructural PMP22 expression in inherited demyelinating neuropathies. Ann Neurol. 1996;39:813-7.

[16] Katona I, Wu X, Feely SM, Sottile S, Siskind CE, Miller LJ, et al. PMP22 expression in dermal nerve myelin from patients with CMT1A. Brain. 2009;132:1734-40.

[17] Fledrich R, Schlotter-Weigel B, Schnizer TJ, Wichert SP, Stassart RM, Meyer zu Horste G, et al. A rat model of Charcot-Marie-Tooth disease 1A recapitulates disease variability and supplies biomarkers of axonal loss in patients. Brain. 2012;135:72-87.

[18] Li J, Ghandour K, Radovanovic D, Shy RR, Krajewski KM, Shy ME, et al. Stoichiometric alteration of PMP22 protein determines the phenotype of hereditary neuropathy with liability to pressure palsies. Arch Neurol. 2007;64:974-8.

[19] Ayers MM, Anderson RM. Onion bulb neuropathy in the trembler mouse: a model of hypertrophic interstitial neuropathy (Dejerine-Sottas) in man. Acta Neuropathol. 1973;25:5470. 
[20] Suter U, Welcher AA, Ozcelik T, Snipes GJ, Kosaras B, Francke U, et al. Trembler mouse carries a point mutation in a myelin gene. Nature. 1992;356:241-4.

[21] Sidman RL, Cowen JS, Eicher EM. Inherited muscle and nerve diseases in mice: a tabulation with commentary. Ann N Y Acad Sci. 1979;317:497-505.

[22] Suter U, Moskow JJ, Welcher AA, Snipes GJ, Kosaras B, Sidman RL, et al. A leucineto-proline mutation in the putative first transmembrane domain of the 22-kDa peripheral myelin protein in the trembler-J mouse. Proc Natl Acad Sci U S A. 1992;89:4382-6.

[23] Robertson AM, Huxley C, King RH, Thomas PK. Development of early postnatal peripheral nerve abnormalities in Trembler-J and PMP22 transgenic mice. J Anat. $1999 ; 195: 331-9$

[24] Low PA, McLeod JG. Hereditary demyelinating neuropathy in the trembler mouse. J Neurol Sci. 1975;26:565-74.

[25] Rosenbluth J, Bobrowski-Khoury N. Paranodal dysmyelination in peripheral nerves of Trembler mice. J Neurosci Res. 2014.

[26] Colby J, Nicholson R, Dickson KM, Orfali W, Naef R, Suter U, et al. PMP22 carrying the trembler or trembler-J mutation is intracellularly retained in myelinating Schwann cells. Neurobiol Dis. 2000;7:561-73.

[27] Ryan MC, Shooter EM, Notterpek L. Aggresome formation in neuropathy models based on peripheral myelin protein 22 mutations. Neurobiol Dis. 2002;10:109-18.

[28] Fortun J, Verrier JD, Go JC, Madorsky I, Dunn WA, Notterpek L. The formation of peripheral myelin protein 22 aggregates is hindered by the enhancement of autophagy and expression of cytoplasmic chaperones. Neurobiol Dis. 2007;25:252-65.

[29] Henry EW, Cowen JS, Sidman RL. Comparison of Trembler and Trembler-J mouse phenotypes: varying severity of peripheral hypomyelination. J Neuropathol Exp Neurol. $1983 ; 42: 688-706$. 
[30] Suh JG, Ichihara N, Saigoh K, Nakabayashi O, Yamanishi T, Tanaka K, et al. An inframe deletion in peripheral myelin protein-22 gene causes hypomyelination and cell death of the Schwann cells in the new Trembler mutant mice. Neuroscience. 1997;79:735-44.

[31] Isaacs AM, Davies KE, Hunter AJ, Nolan PM, Vizor L, Peters J, et al. Identification of two new Pmp22 mouse mutants using large-scale mutagenesis and a novel rapid mapping strategy. Hum Mol Genet. 2000;9:1865-71.

[32] Isaacs AM, Jeans A, Oliver PL, Vizor L, Brown SD, Hunter AJ, et al. Identification of a new Pmp22 mouse mutant and trafficking analysis of a Pmp22 allelic series suggesting that protein aggregates may be protective in Pmp22-associated peripheral neuropathy. Mol Cell Neurosci. 2002;21:114-25.

[33] Valentijn LJ, Ouvrier RA, van den Bosch NH, Bolhuis PA, Baas F, Nicholson GA. Dejerine-Sottas neuropathy is associated with a de novo PMP22 mutation. Hum Mutat. $1995 ; 5: 76-80$.

[34] Rossor AM, Tomaselli PJ, Reilly MM. Recent advances in the genetic neuropathies. Curr Opin Neurol. 2016;29:537-48.

[35] Mathis S, Goizet C, Tazir M, Magdelaine C, Lia AS, Magy L, et al. Charcot-MarieTooth diseases: an update and some new proposals for the classification. J Med Genet. 2015;52:681-90.

[36] Planté-Bordeneuve V, Parman Y, Guiochon-Mantel A, Alj Y, Deymeer F, Serdaroglu P, et al. The range of chronic demyelinating neuropathy of infancy: a clinico-pathological and genetic study of 15 unrelated cases. J Neurol. 2001;248:795-803.

[37] Simonati A, Fabrizi GM, Pasquinelli A, Taioli F, Cavallaro T, Morbin M, et al. Congenital hypomyelination neuropathy with Ser72Leu substitution in PMP22. Neuromuscul Disord. 1999;9:257-61. 
[38] Marques W, Jr., Neto JM, Barreira AA. Dejerine-Sottas' neuropathy caused by the missense mutation PMP22 Ser72Leu. Acta Neurol Scand. 2004;110:196-9.

[39] Madrid RE, Lofgren A, Baets J, Timmerman V. Biopsy in a patient with PMP22 exon 2 mutation recapitulates pathology of Trembler-J mouse. Neuromuscul Disord. 2013;23:345-8. [40] Gabreels-Festen A, Wetering RV. Human nerve pathology caused by different mutational mechanisms of the PMP22 gene. Ann N Y Acad Sci. 1999;883:336-43. [41] Tyson J, Ellis D, Fairbrother U, King RH, Muntoni F, Jacobs J, et al. Hereditary demyelinating neuropathy of infancy. A genetically complex syndrome. Brain. 1997;120:4763.

[42] Ohnishi A, Yamamoto T, Izawa K, Yamamori S, Takahashi K, Mega H, et al. Dejerinesottas disease with a novel de novo dominant mutation, Ser 149 Arg, of the peripheral myelin protein 22. Acta Neuropathol. 2000;99:327-30.

[43] Vital A, Vital C, Latour P, Ferrer X, Rouanet-Lariviere M, Brechenmacher C, et al. Peripheral nerve biopsy study in 19 cases with 17p11.2 deletion. J Neuropathol Exp Neurol. 2004;63:1167-72.

[44] Pisciotta C, Manganelli F, Iodice R, Bellone E, Geroldi A, Volpi N, et al. Two families with novel PMP22 point mutations: genotype-phenotype correlation. J Peripher Nerv Syst. 2009;14:208-12.

[45] Fabrizi GM, Cavallaro T, Taioli F, Orrico D, Morbin M, Simonati A, et al. Myelin uncompaction in Charcot-Marie-Tooth neuropathy type 1A with a point mutation of peripheral myelin protein-22. Neurology. 1999;53:846-51.

[46] Giambonini-Brugnoli G, Buchstaller J, Sommer L, Suter U, Mantei N. Distinct disease mechanisms in peripheral neuropathies due to altered peripheral myelin protein 22 gene dosage or a Pmp22 point mutation. Neurobiol Dis. 2005;18:656-68. 
[47] Sereda M, Griffiths I, Puhlhofer A, Stewart H, Rossner MJ, Zimmerman F, et al. A transgenic rat model of Charcot-Marie-Tooth disease. Neuron. 1996;16:1049-60.

[48] Magyar JP, Martini R, Ruelicke T, Aguzzi A, Adlkofer K, Dembic Z, et al. Impaired differentiation of Schwann cells in transgenic mice with increased PMP22 gene dosage. J Neurosci. 1996;16:5351-60.

[49] Huxley C, Passage E, Robertson AM, Youl B, Huston S, Manson A, et al. Correlation between varying levels of PMP22 expression and the degree of demyelination and reduction in nerve conduction velocity in transgenic mice. Hum Mol Genet. 1998;7:449-58.

[50] Huxley C, Passage E, Robertson AM, Youl B, Huston S, Manson A, et al. Correlation between varying levels of PMP22 expression and the degree of demyelination and reduction in nerve conduction velocity in transgenic mice. Hum Mol Genet. 1998;7:449-58.

[51] Passage E, Norreel JC, Noack-Fraissignes P, Sanguedolce V, Pizant J, Thirion X, et al. Ascorbic acid treatment corrects the phenotype of a mouse model of Charcot-Marie-Tooth disease. Nat Med. 2004;10:396-401.

[52] Li J, Parker B, Martyn C, Natarajan C, Guo J. The PMP22 gene and its related diseases. Mol Neurobiol. 2013;47:673-98.

[53] Niemann S, Sereda MW, Suter U, Griffiths IR, Nave KA. Uncoupling of myelin assembly and schwann cell differentiation by transgenic overexpression of peripheral myelin protein 22. J Neurosci. 2000;20:4120-8.

[54] Chittoor VG, Sooyeon L, Rangaraju S, Nicks JR, Schmidt JT, Madorsky I, et al. Biochemical characterization of protein quality control mechanisms during disease progression in the C22 mouse model of CMT1A. ASN Neuro. 2013;5:e0128.

[55] Chittoor-Vinod VG, Lee S, Judge SM, Notterpek L. Inducible HSP70 is critical in preventing the aggregation and enhancing the processing of PMP22. ASN Neuro. 2015;7. 
[56] Hanemann CO, D'Urso D, Gabreels-Festen AA, Muller HW. Mutation-dependent alteration in cellular distribution of peripheral myelin protein 22 in nerve biopsies from Charcot-Marie-Tooth type 1A. Brain. 2000;123:1001-6.

[57] Vallat JM. Dominantly inherited peripheral neuropathies. J Neuropathol Exp Neurol. 2003;62:699-714.

[58] Fabrizi GM, Simonati A, Taioli F, Cavallaro T, Ferrarini M, Rigatelli F, et al. PMP22 related congenital hypomyelination neuropathy. J Neurol Neurosurg Psychiatry. 2001;70:1236.

[59] Nave KA, Werner HB. Myelination of the nervous system: mechanisms and functions. Annu Rev Cell Dev Biol. 2014;30:503-33.

[60] Amici SA, Dunn WA, Jr., Notterpek L. Developmental abnormalities in the nerves of peripheral myelin protein 22-deficient mice. J Neurosci Res. 2007;85:238-49.

[61] Jetten AM, Suter U. The peripheral myelin protein 22 and epithelial membrane protein family. Prog Nucleic Acid Res Mol Biol. 2000;64:97-129.

[62] Sancho S, Young P, Suter U. Regulation of Schwann cell proliferation and apoptosis in PMP22-deficient mice and mouse models of Charcot-Marie-Tooth disease type 1A. Brain. 2001;124:2177-87.

[63] Rosso G, Negreira C, Sotelo JR, Kun A. Myelinating and demyelinating phenotype of Trembler-J mouse (a model of Charcot-Marie-Tooth human disease) analyzed by atomic force microscopy and confocal microscopy. J Mol Recognit. 2012;25:247-55.

[64] Rosso G, Liashkovich I, Gess B, Young P, Kun A, Shahin V. Unravelling crucial biomechanical resilience of myelinated peripheral nerve fibres provided by the Schwann cell basal lamina and PMP22. Sci Rep. 2014;4:7286.

[65] Guo J, Wang L, Zhang Y, Wu J, Arpag S, Hu B, et al. Abnormal junctions and permeability of myelin in PMP22-deficient nerves. Ann Neurol. 2014;75:255-65. 
[66] Mathis S, Magy L, Vallat JM. Therapeutic options in Charcot-Marie-Tooth diseases. Expert Rev Neurother. 2015;15:355-66.

[67] Chumakov I, Milet A, Cholet N, Primas G, Boucard A, Pereira Y, et al. Polytherapy with a combination of three repurposed drugs (PXT3003) down-regulates Pmp22 over-expression and improves myelination, axonal and functional parameters in models of CMT1A neuropathy. Orphanet J Rare Dis. 2014;9:201.

[68] Gess B, Baets J, De Jonghe P, Reilly MM, Pareyson D, Young P. Ascorbic acid for the treatment of Charcot-Marie-Tooth disease. Cochrane Database Syst Rev. 2015;12:CD011952. [69] Sahenk Z, Nagaraja HN, McCracken BS, King WM, Freimer ML, Cedarbaum JM, et al. NT-3 promotes nerve regeneration and sensory improvement in CMT1A mouse models and in patients. Neurology. 2005;65:681-9.

[70] Fledrich R, Abdelaal T, Rasch L, Bansal V, Schutza V, Brugger B, et al. Targeting myelin lipid metabolism as a potential therapeutic strategy in a model of CMT1A neuropathy. Nat Commun. 2018;9:3025.

[71] Zhao HT, Damle S, Ikeda-Lee K, Kuntz S, Li J, Mohan A, et al. PMP22 antisense oligonucleotides reverse Charcot-Marie-Tooth disease type 1A features in rodent models. J Clin Invest. 2018;128:359-68.

[72] Lee JS, Chang EH, Koo OJ, Jwa DH, Mo WM, Kwak G, et al. Pmp22 mutant allelespecific siRNA alleviates demyelinating neuropathic phenotype in vivo. Neurobiol Dis. 2017;100:99-107.

[73] Juneja M, Burns J, Saporta MA, Timmerman V. Challenges in modelling the CharcotMarie-Tooth neuropathies for therapy development. J Neurol Neurosurg Psychiatry. 2018;9058-67. 


\section{First steps of the history of the genetic analysis of CMT/HNPP}

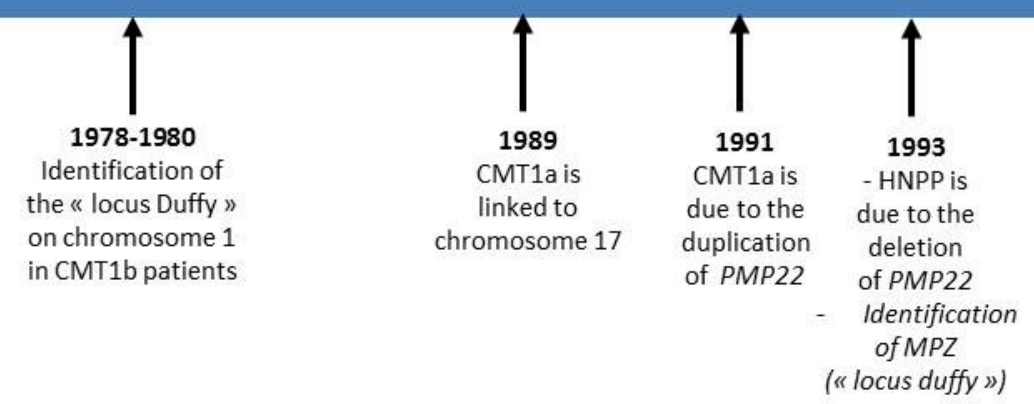

\section{PMP22 mutation models}

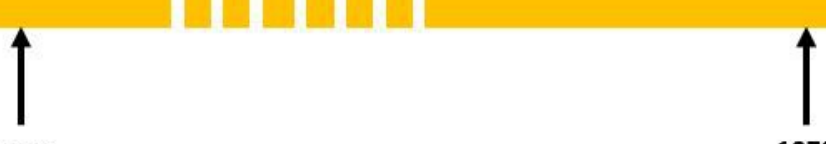

1946

First Trembler (Tr)

animals

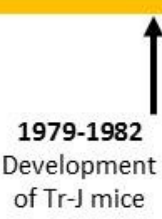

$\begin{array}{cc}\text { First PNS } & \text { Development } \\ \text { of Tr-J mice }\end{array}$

observed in

Tr mice

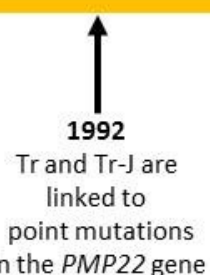

in the PMP22 gene

\section{PMP22 overexpression models}




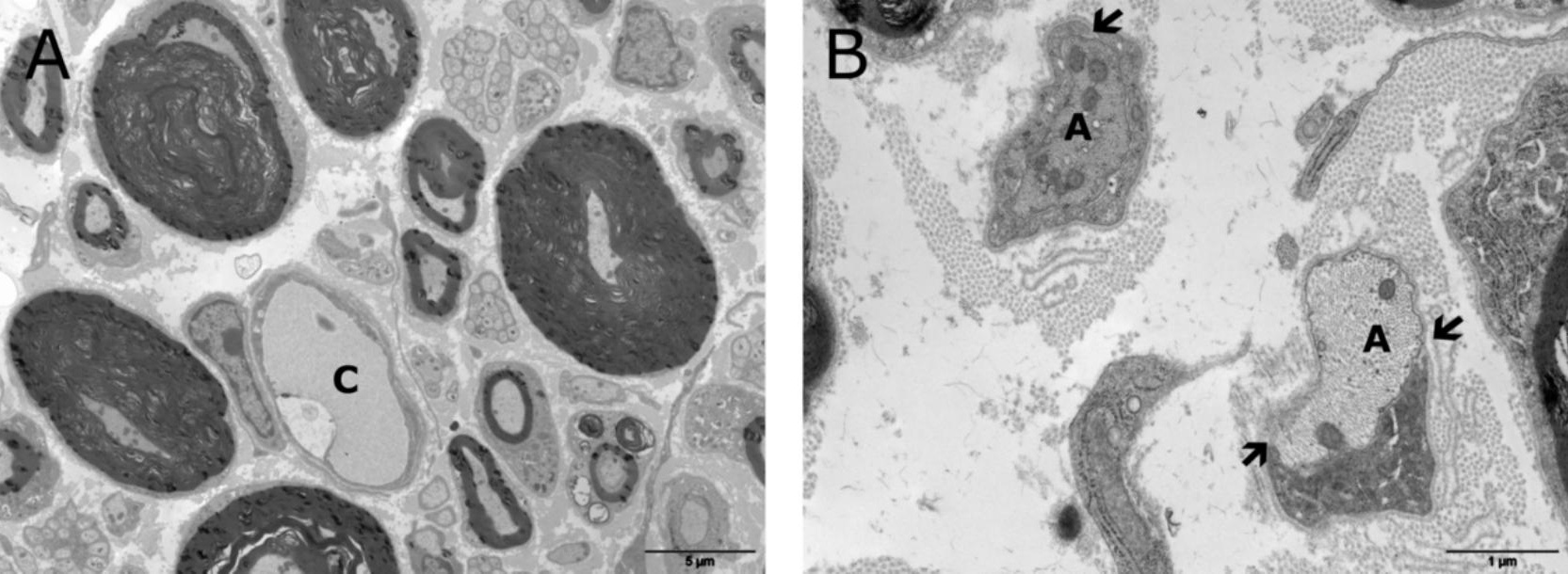




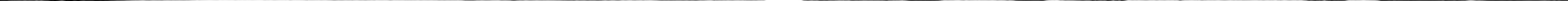




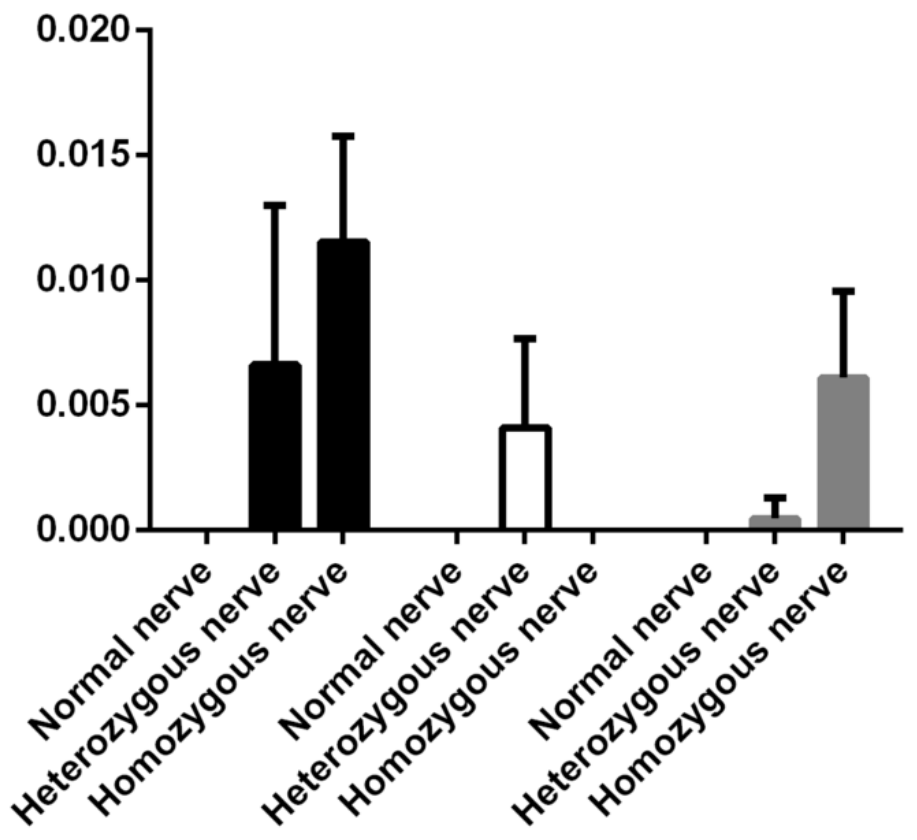

Non myelinated fibers

$\square$ Dysmyelination

Tomacula 


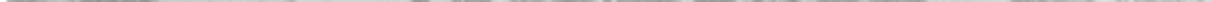




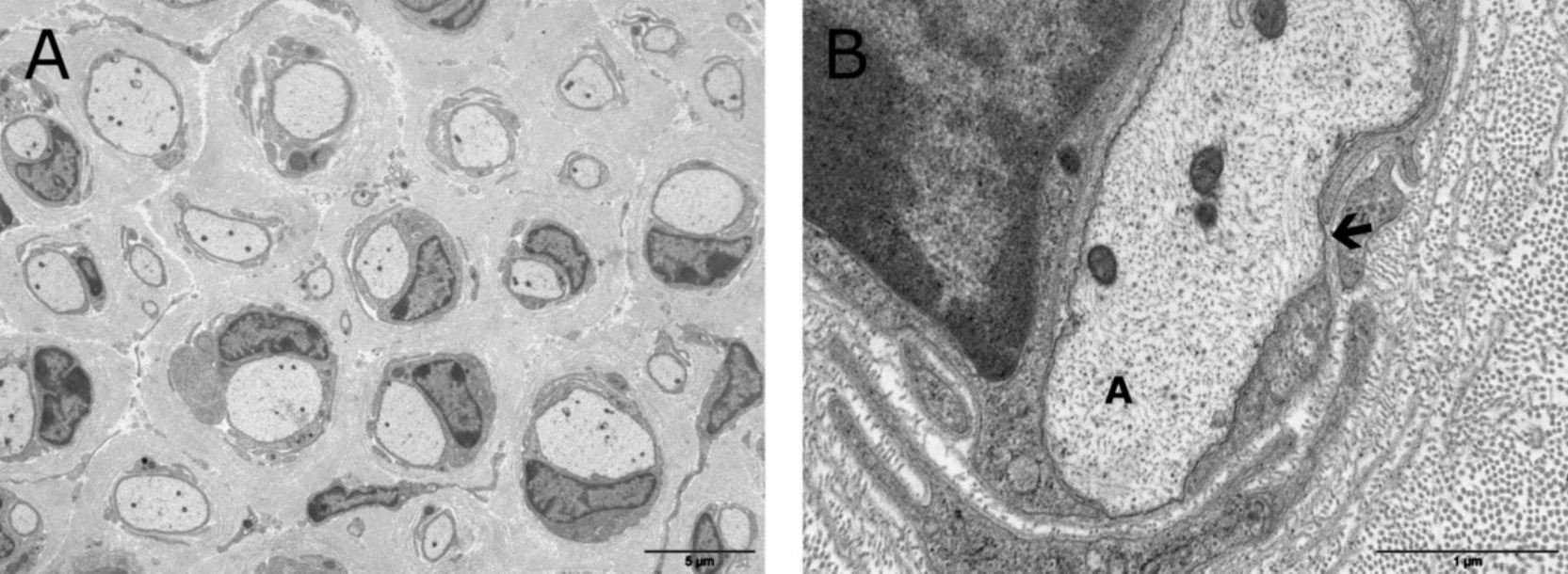


$A, 000^{k} \bigcirc \bigcirc B$

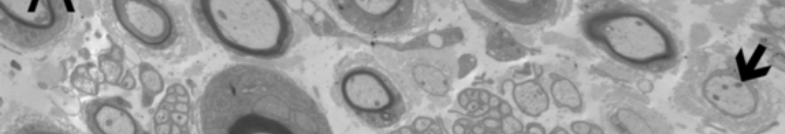
$\begin{array}{cccc}0 & 0 & 0 \\ 0 & 0 & 0 \\ 0 & 0 & 0 & 0 \\ 0 & 0 & 0\end{array}$

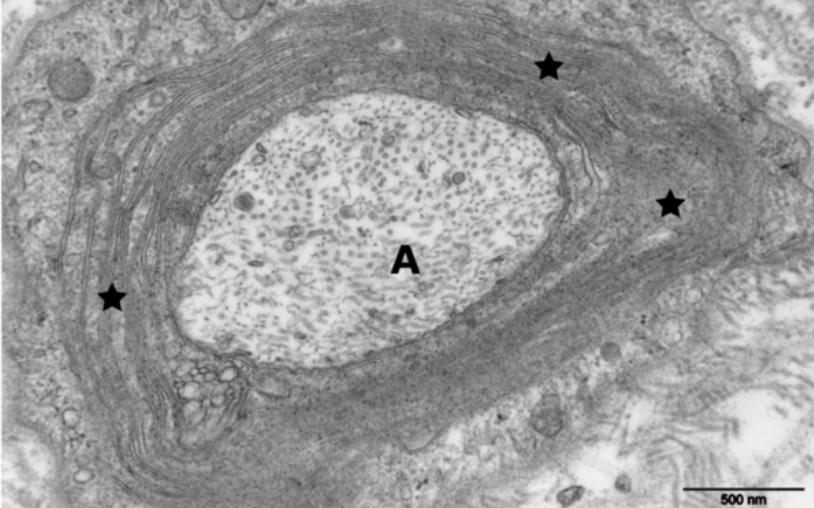


$A \quad \angle 0, \quad B=0$ . $a$
0
0 .
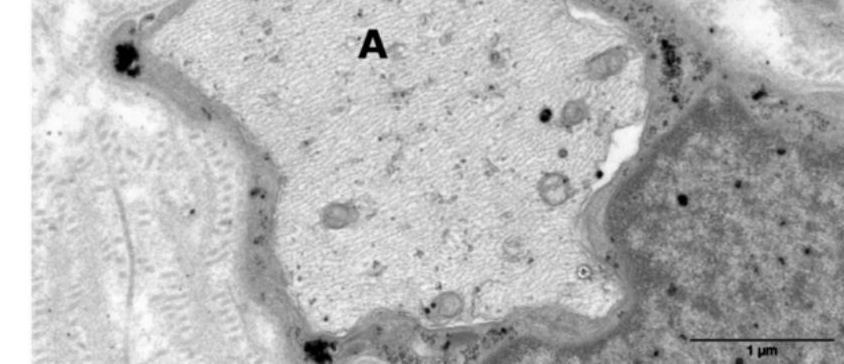


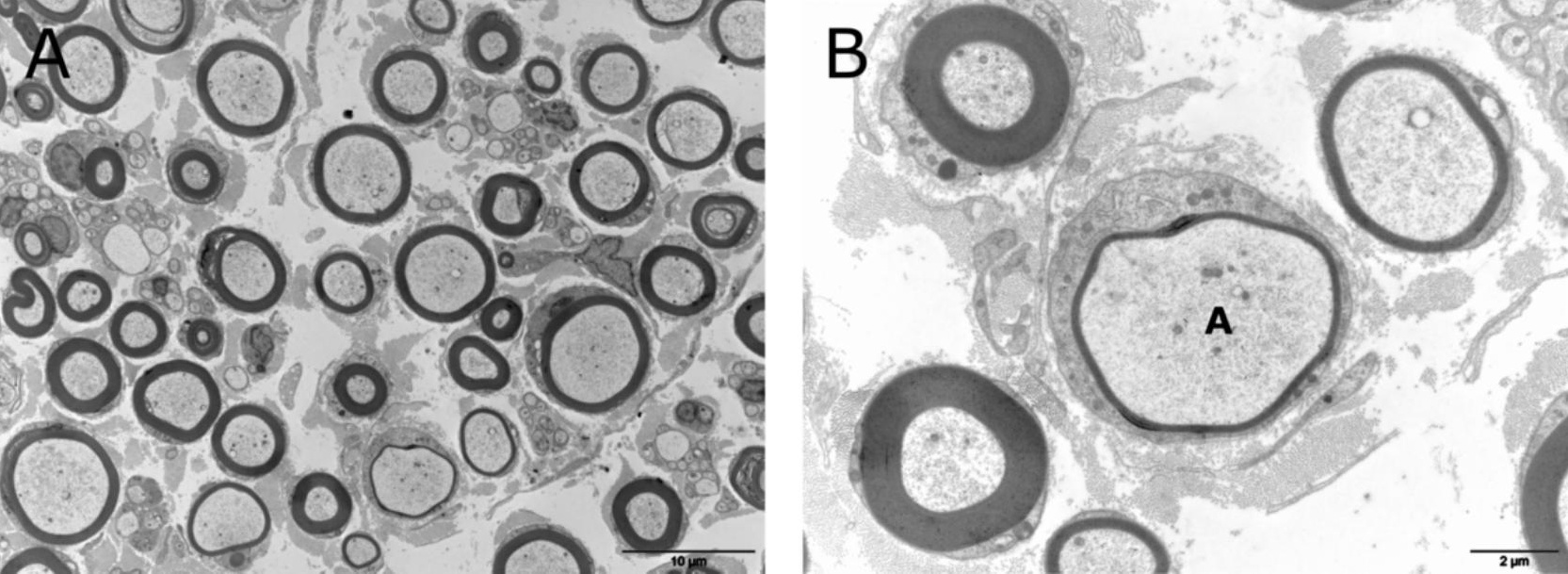




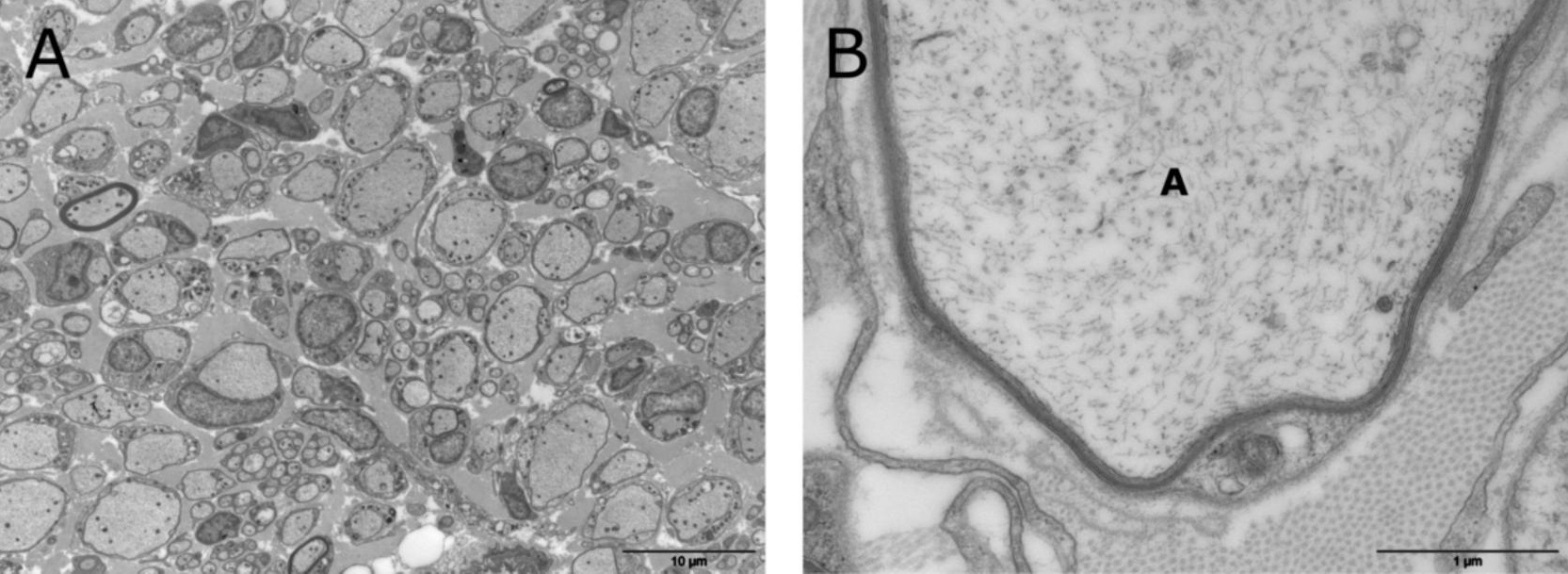



Table 1. Main animal models linked to alterations in the $P M P 22$ gene $(\mathrm{m} / \mathrm{s}=$ meter/second; $\mathrm{n} . \mathrm{a} .=$ not available, $\mathrm{NCV}=\mathrm{Nerve}$ conduction velocities).

\begin{tabular}{|c|c|c|c|c|c|c|c|c|}
\hline & Model name & $\begin{array}{l}\text { First full } \\
\text { description of } \\
\text { the genetic } \\
\text { abnormalities }\end{array}$ & PMP22 modification & $\begin{array}{l}\text { PMP22/mRNA } \\
\text { expression }\end{array}$ & Clinical phenotype & Nerve pathology & $\begin{array}{l}\text { Motor } \\
\text { NCV }\end{array}$ & References \\
\hline \multirow{3}{*}{$\begin{array}{c}\text { PMP22 } \\
\text { downregulation } \\
\text { models }\end{array}$} & $\begin{array}{c}\text { Homozygous } \\
\text { PMP22 KO mouse }\end{array}$ & 1999 & $\begin{array}{l}\text { deletion of } P M P 22 \text { on both } \\
\text { alleles }\end{array}$ & $\begin{array}{l}\text { no PMP22 protein } \\
\text { expression }\end{array}$ & $\begin{array}{l}\text {-walking difficulties } \\
\text {-mild tremor } \\
\text {-stress-induced convulsions }\end{array}$ & $\begin{array}{l}\text {-tomacula } \\
\text {-some large caliber axons without } \\
\text { myelin and without mesaxon } \\
\text {-delay of myelination }\end{array}$ & $10 \mathrm{~m} / \mathrm{s}$ & $\begin{array}{l}\text { Sancho et al. } \\
1999\end{array}$ \\
\hline & $\begin{array}{c}\text { Heterozygous } \\
\text { PMP22 KO mouse }\end{array}$ & 1999 & $\begin{array}{l}\text { deletion of } P M P 22 \text { on one } \\
\text { allele }\end{array}$ & $\begin{array}{l}\text { half normal amount of } \\
\text { PMP22 protein }\end{array}$ & -paralysis of the hind limbs & $\begin{array}{l}\text {-prominent myelin thickenings } \\
\text {-large caliber axons devoid of myelin } \\
\text { sheaths }\end{array}$ & n.a. & $\begin{array}{l}\text { Sancho et al. } \\
1999\end{array}$ \\
\hline & $\begin{array}{l}\text { PMP22 deficient } \\
\text { Lac Z }\end{array}$ & 2006 & $\begin{array}{l}P M P 22 \text { gene replaced by } \\
\text { Lac } \mathrm{Z} \text { reporter }\end{array}$ & no PMP22 expression & -visible signs of motor deficit & $\begin{array}{l}\text {-pockets of loose basal lamina } \\
\text {-axons without myelin }\end{array}$ & n.a. & $\begin{array}{l}\text { Amici et al. } \\
2006\end{array}$ \\
\hline \multirow{7}{*}{$\begin{array}{c}\text { PMP22 } \\
\text { mutation } \\
\text { models }\end{array}$} & $\begin{array}{l}\text { Homozygous } \\
\text { Trembler mouse }\end{array}$ & 1992 & $\begin{array}{l}\text { point mutation on the two } \\
P M P 22 \text { gene on } \\
\text { chromosome } 11\end{array}$ & $\begin{array}{l}\text { PMP22 with the } \\
\text { Gly150Asp missense } \\
\text { mutation }\end{array}$ & $\begin{array}{l}\text {-quadriparesis } \\
\text {-strong body tremor } \\
\text {-convulsions }\end{array}$ & -almost completely devoid of myelin & n.a. & $\begin{array}{l}\text { Suter et al. } \\
1992\end{array}$ \\
\hline & $\begin{array}{c}\text { Heterozygous } \\
\text { Trembler mouse }\end{array}$ & 1992 & $\begin{array}{l}\text { point mutation on one } \\
\text { allele of } P M P 22\end{array}$ & $\begin{array}{l}\text { half normal protein and } \\
\text { half Gly150Asp protein }\end{array}$ & $\begin{array}{l}\text {-spastic paralysis } \\
\text {-generalized tremor }\end{array}$ & $\begin{array}{l}\text {-severe hypomyelination } \\
\text { - 'onion bulb' formations }\end{array}$ & $2.51 \mathrm{~m} / \mathrm{s}$ & $\begin{array}{l}\text { Suter et al. } \\
1992\end{array}$ \\
\hline & $\begin{array}{c}\text { Homozygous } \\
\text { Trembler-J mouse }\end{array}$ & 1992 & $\begin{array}{l}\text { homozygous point } \\
\text { mutation on } P M P 22 \text { gene }\end{array}$ & $\begin{array}{l}\text { PMP22 protein with the } \\
\text { Leu16Pro missense point } \\
\text { mutation }\end{array}$ & $\begin{array}{l}\text {-unable to work normally } \\
\text {-dead by } 18 \text { days } \\
\text {-strong tremor } \\
\text {-paralysis of the rear trunk }\end{array}$ & $\begin{array}{l}\text {-nearly devoid of myelin } \\
\text {-myelinogenesis blocked at } \\
\text { promyelinating stage }\end{array}$ & n.a. & $\begin{array}{l}\text { Valentjin et } \\
\text { al. } 1992\end{array}$ \\
\hline & $\begin{array}{c}\text { Heterozygous } \\
\text { Trembler-J mouse }\end{array}$ & 1992 & $\begin{array}{l}\text { heterozygous point } \\
\text { mutation on } P M P 22\end{array}$ & $\begin{array}{l}\text { half normal protein and } \\
\text { half Leu16Pro protein }\end{array}$ & -mild gait abnormalities & -mild late onset demyelination & $12.3 \mathrm{~m} / \mathrm{s}$ & $\begin{array}{l}\text { Valentjin et } \\
\text { al. } 1992\end{array}$ \\
\hline & $\begin{array}{l}\text { Homozygous } \\
\text { Trembler Ncnp }\end{array}$ & 1997 & $\begin{array}{l}\text { spontaneous autosomal } \\
\text { dominant PMP22 exon } 4 \\
\text { deletion on the two alleles }\end{array}$ & n.a. & -unable to walk normally & -no myelin & n.a. & $\begin{array}{l}\text { Suh et al. } \\
1997\end{array}$ \\
\hline & $\begin{array}{l}\text { Heterozygous } \\
\text { Trembler Ncnp }\end{array}$ & 1997 & $\begin{array}{l}\text { spontaneous autosomal } \\
\text { dominant } P M P 22 \text { exon } 4 \\
\text { deletion on one allele }\end{array}$ & n.a. & $\begin{array}{l}\text {-gait abnormalities increasing } \\
\text { slighty with age }\end{array}$ & $\begin{array}{l}\text {-variable demyelination } \\
\text {-segmental basal lamella irregularly } \\
\text { surrounds axons }\end{array}$ & n.a. & $\begin{array}{l}\text { Suh et al. } \\
1997\end{array}$ \\
\hline & $\begin{array}{l}\text { Trembler M1H } \\
\text { and M2H }\end{array}$ & 2000 & $\begin{array}{l}\text { heterozygous point } \\
\text { mutation on PMP22 gene: } \\
\text {-H12R for M1H } \\
\text {-Y153TER for M2H }\end{array}$ & n.a. & $\begin{array}{l}\text {-resting tremor } \\
\text {-low locomotor activity } \\
\text {-abnormal gait and motor } \\
\text { coordination }\end{array}$ & $\begin{array}{l}\text {-hypomyelination } \\
\text {-axonal loss }\end{array}$ & n.a. & $\begin{array}{l}\text { Isaacs et al. } \\
2000\end{array}$ \\
\hline \multirow{3}{*}{$\begin{array}{l}\text { PMP22 } \\
\text { overexpression } \\
\text { models }\end{array}$} & $\begin{array}{l}\text { Homozygous } \\
\text { CMT1A rat }\end{array}$ & 1996 & $\begin{array}{l}\text { transgenic line with six } \\
\text { supplementary mice } \\
\text { PMP22 transgene copies }\end{array}$ & $\begin{array}{l}\text { overexpression of the } \\
\text { PMP22 gene (dosage- } \\
\text { dependent) }\end{array}$ & -hind limb paralysis & -very thin myelin sheath & n.a. & $\begin{array}{l}\text { Sereda et al. } \\
1996\end{array}$ \\
\hline & $\begin{array}{l}\text { Heterozygous } \\
\text { CMT1A rat }\end{array}$ & 1996 & $\begin{array}{l}\text { transgenic line with three } \\
\text { supplementary mice } \\
\text { PMP22 transgene copies }\end{array}$ & $\begin{array}{l}\text { overexpression of the } \\
P M P 22 \text { gene (dosage- } \\
\text { dependent) }\end{array}$ & $\begin{array}{l}\text {-unsteadiness of gait } \\
\text {-strong variability of } \\
\text { phenotypes between individuals }\end{array}$ & $\begin{array}{l}\text {-general hypomyelination } \\
\text {-thin or absent myelin sheath } \\
\text {-strong variability og phenotypes } \\
\text { between individuals }\end{array}$ & $14.7 \mathrm{~m} / \mathrm{s}$ & $\begin{array}{l}\text { Sereda et al. } \\
1996\end{array}$ \\
\hline & Mouse C22 & 1996 & $\begin{array}{l}\text { transgenic line with seven } \\
\text { supplementary mice }\end{array}$ & $\begin{array}{l}\text { overexpression of the } \\
P M P 22 \text { gene }\end{array}$ & $\begin{array}{l}\text {-weakness and progressive } \\
\text { paralysis of hind legs }\end{array}$ & $\begin{array}{l}\text {-widespread demyelination of large } \\
\text { axons }\end{array}$ & $4 \mathrm{~m} / \mathrm{s}$ & $\begin{array}{l}\text { Magyar et } \\
\text { al. } 1996\end{array}$ \\
\hline
\end{tabular}




\begin{tabular}{|c|c|c|c|c|c|c|c|c|}
\hline & & & PMP22 transgene copies & & & -'onion bulb' formations & & \\
\hline & Mouse C61 & 1996 & $\begin{array}{l}\text { transgenic line with eight } \\
\text { supplementary mice } \\
\text { PMP22 transgene copies }\end{array}$ & $\begin{array}{l}\text { overexpression of the } \\
P M P 22 \text { gene }\end{array}$ & $\begin{array}{l}\text {-weakness and progressive } \\
\text { paralysis of hind legs }\end{array}$ & $\begin{array}{l}\text {-widespread demyelination of large } \\
\text { axons } \\
\text {-'onion bulb' formations }\end{array}$ & $4 \mathrm{~m} / \mathrm{s}$ & $\begin{array}{l}\text { Magyar et } \\
\text { al. } 1996\end{array}$ \\
\hline
\end{tabular}

